\title{
Role of growth hormone in development and maintenance of follicles and corpora lutea
}

\author{
M. C. Lucy, C. R. Bilby*, C. J. Kirby ${ }^{\ddagger}$, W. Yuan ${ }^{\ddagger}$ and C. K. Boyd \\ 164 Animal Sciences Research Center, University of Missouri, Columbia, MO 65211, USA
}

\begin{abstract}
Growth hormone $(\mathrm{GH})$ is a pituitary hormone that affects animal growth, metabolism, lactation, and reproduction. Many of the effects of GH are mediated by insulin-like growth factor I (IGF-I) which is synthesized in liver and ovary in response to GH. Insulin-like growth factor I synergizes with gonadotrophins (LH and FSH) to stimulate growth and differentiation of ovarian cells. There are species differences in the effects of GH in reproductive biology. In most species, ovarian follicles and corpora lutea are potential sites for $\mathrm{GH}$ action because the $\mathrm{GH}$ receptor is found within granulosal cells as well as corpora lutea. However, growth hormone does not control ovarian IGF-I in all species and, in ruminants, endocrine IGF-I from liver may be the principal mediator of GH action. In cattle, administration of $\mathrm{GH}$ increases the number of small antral ovarian follicles but does not increase the number of large antral (dominant) follicles. Growth hormone may antagonize some aspects of dominant follicular function because dominant follicles are shorter-lived in $\mathrm{GH}$-treated cattle. The corpora lutea has increased growth and steroidogenesis in response to GH. Growth hormone-induced steroidogenesis in cultured granulosal and luteal cells depends on IGF-I release after GH treatment. Bovine and ovine granulosal cells do not release IGF-I in response to $\mathrm{GH}$ in vitro and, therefore, are less responsive to $\mathrm{GH}$. These results demonstrate that $\mathrm{GH}$ is required for normal reproductive function in ruminant as well as nonruminant species.
\end{abstract}

\section{Introduction}

Growth hormone (GH) is a product of the pituitary somatotroph. As its name implies, GH is involved in animal growth. However, its actions are not confined to the growing animal and it is now clear that numerous metabolic and physiological processes (including reproduction) of the adult animal are controlled partially by GH. After its release from the pituitary, $\mathrm{GH}$ can act on a variety of tissues because cell-surface receptors for GH are widely distributed throughout the ruminant body (Lucy et $a l$, 1998; Fig. 1). Reproductive tissues that contain mRNA for GH receptor include hypothalamus, pituitary, corpus luteum, ovarian follicle, oviduct, endometrium, myometrium, and placenta (Kirby et al, 1996; Lucy et al., 1998). The highest amount of GH receptor is in the liver, where GH binding causes an increase in the synthesis and secretion of insulin-like growth factor I (IGF)-I. Insulin-like growth factor-I complexes with one of a series of IGF-binding proteins (IGFBP) and then travels as an endocrine hormone to stimulate several additional physiological and metabolic processes including those required for reproduction (Spicer and Echternkamp, 1995; Armstrong and Webb, 1997).

\section{Ovarian IGF Physiology}

The focus of this review is GH and ovarian function. A brief discussion of ovarian IGF-I physiology is necessary because many of the actions of GH are mediated by IGF-I. Insulin-like growth factor II

*Present address: Monsanto Company, St. Louis, MO 63198, USA.

Present Address: College of Veterinary Mediçine, North Carolina State University, Raleigh, NC 27606, USA.

tPresent Address: Department of Gynecology and Obstetrics, Stanford University School of Medicine, Stanford, CA 94305, USA

(a) 1999 Journals of Reproduction and Fertility Ltd 


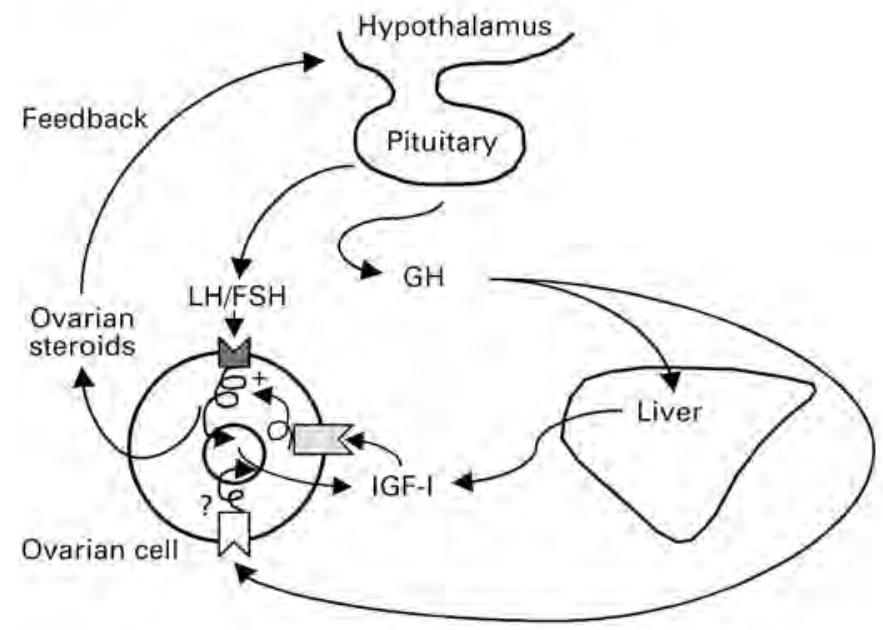

Fig. 1. Model for the actions of growth hormone (GH) and insulinlike growth factor 1 (IGF-I) on ovarian cells. The model represents general mechanisms that may or may not be proven in all ovarian cell types (thecal, granulosal and luteal) or in all species. Some of the effects of $\mathrm{GH}$ are mediated directly by $\mathrm{GH}$ at the ovary. The ovarian response may involve the synthesis and secretion of IGF-I by ovarian cells. An endocrine effect is also associated with $\mathrm{GH}$ because $\mathrm{GH}$ can bind to liver receptors and increase blood IGF-I that can affect ovarian function. Insulin-like growth factor I is synergistic with gonadotrophins for its effect on ovarian cells because gonadotrophins increase IGF-I and IGF receptor synthesis and IGF-I increases gonadotrophin receptor expression and second messenger systems. The synergy increases ovarian cell steroidogenesis. Ovarian function is linked to hypothalamic and pituitary function because oestradiol feeds back positively on GH secretion which can ultimately lead to increased concentrations of IGF-I reaching the ovary. In addition, nutritionally induced changes in liver function can alter ovarian function by modifying the amount of endocrine IGF-I.

has similar effects to IGF-I on ovarian cells but has lower potency than IGF-I and is not under GH control. Granulosal, thecal and luteal cells are sites for IGF action (Spicer and Ech:srnkamp, 1995; Armstrong and Webb, 1997). Endocrine IGF-I (from liver) is not the only source of ovarian IGF-I because ovarian cells (granulosal and luteal cells) synthesize IGF-I and contribute to the total amount of IGF-I that reaches the ovary (endocrine plus local ovarian sources). Within the ruminant follicle, IGF-II produced by the theca may be the most important, locally produced IGF, because thecal IGF-II synthesis is greater than granulosal cell IGF-I synthesis (Yuan et al., 1998). There is synergy between IGF-I and gonadotrophins (LH and FSH) that explains some of the actions of the IGF on ovarian cells. A maximal effect of IGF-I or IGF-II is only observed when cells are treated in combination with either FSH or LH (Spicer and Echternkamp, 1995). Gonadotrophins maintain IGF action by stimulating IGF-I and IGF receptor expression. Furthermore, IGF-I increases gonadotrophin responsiveness by stimulating the adenylate cyclase complex (Fig. 1).

\section{Nutritional Regulation of GH and IGF-I}

The release of IGF-I in response to GH within liver is regulated by nutritional status (energy and protein intake relative to requirements; McGuire et al., 1992). The nutritional regulation of IGF-I 


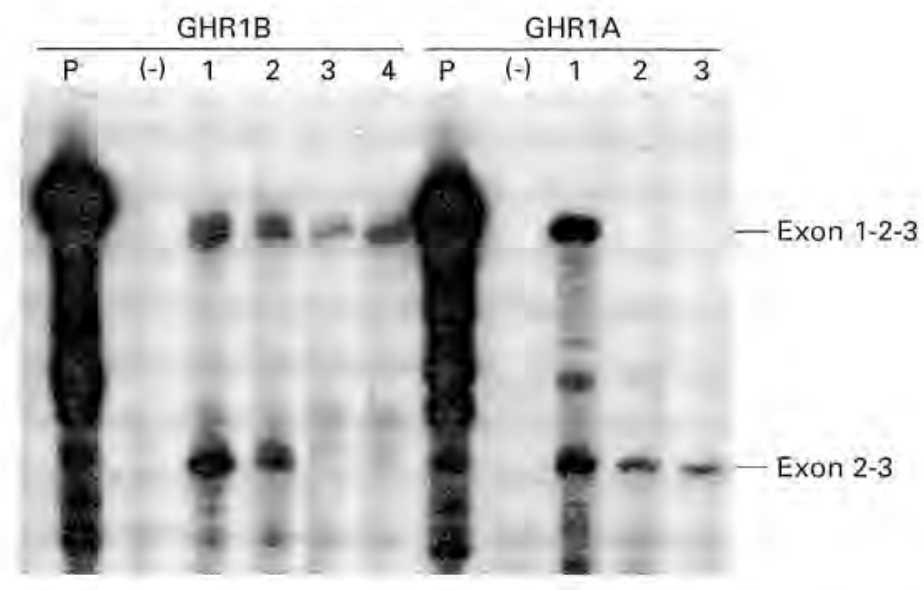

Fig. 2. Ribonuclease protection assay showing alternative splicing of $\mathrm{GH}$ receptor mRNA. The GH receptor mRNA is present in two forms (GHR1A and GHR1B) which are controlled by different promoters (1A and $1 \mathrm{~B}$ ). The GHR1B assay yields a full-length protected fragment (exon 1-2-3) for liver (lanes 1 and 2) and corpus luteum (lanes 3 and 4) showing that the $1 \mathrm{~B}$ promoter is active in liver and corpora lutea. An exon 2-3 fragment is found in liver but not in corpora lutea. Therefore, other alternatively spliced forms of the GH receptor are found in liver but not in corpora lutea. The GHR1A assay yields a full-length protected fragment in liver (lane 1) but only the exon 2-3 fragment in corpora lutea (lanes 2 and 3). The 1A promoter, therefore, is active in liver but not corpora lutea. The exon 2-3 fragment represents GHR1B mRNA found in corpora lutea and liver. $\mathrm{P}=$ undigested probe; $(-)=$ negative control.

should not be ignored when considering the effects of GH on reproduction because IGF-I is an important regulator of follicular and luteal function. Animals fed adequate nutrition have the highest concentration of blood IGF-I. Blood IGF-I is highly correlated with follicular fluid IGF-I because the majority of IGF-I in follicular fluid is derived from blood (Leeuwenberg et al., 1996). Postpartum anoestrous cattle have lower blood IGF-I concentrations than cattle that have resumed oestrous cycles (Roberts et al., 1997). Blood GH concentrations are correlated inversely with blood IGF-I because IGF-I is the primary negative feedback regulator of GH secretion. Therefore, animals with increased blood GH usually have low blood IGF-I. An exception to this relationship is found in animals treated with exogenous GH where both GH and IGF-I are increased. An example of the interplay between liver and ovary within the GH-IGF-I endocrine system is found in postpartum cattle. Insulin-like growth factor I is decreased in postpartum cattle because energy requirements exceed nutrient intake (McGuire et al., 1992). Cattle in poor body condition or cows failing to improve body condition during lactation also have low blood IGF-I. However, blood GH concentrations are higher in postpartum cows with low concentrations of blood IGF-I. Later in the postpartum period, when nutritional deficiencies are corrected, blood IGF-I increases. Greater blood concentrations of IGF-I act on the hypothalamus and pituitary to decrease GH secretion. These changes in GH and IGF-I, which are a consequence of nutritionally induced changes in hepatic function, have a direct effect on the ovary by modifying the amounts GH and IGF-I in blood. Improved postpartum ovarian function is correlated with lower blood concentrations of GH and higher blood IGF-I (Roberts et al., 1997). 

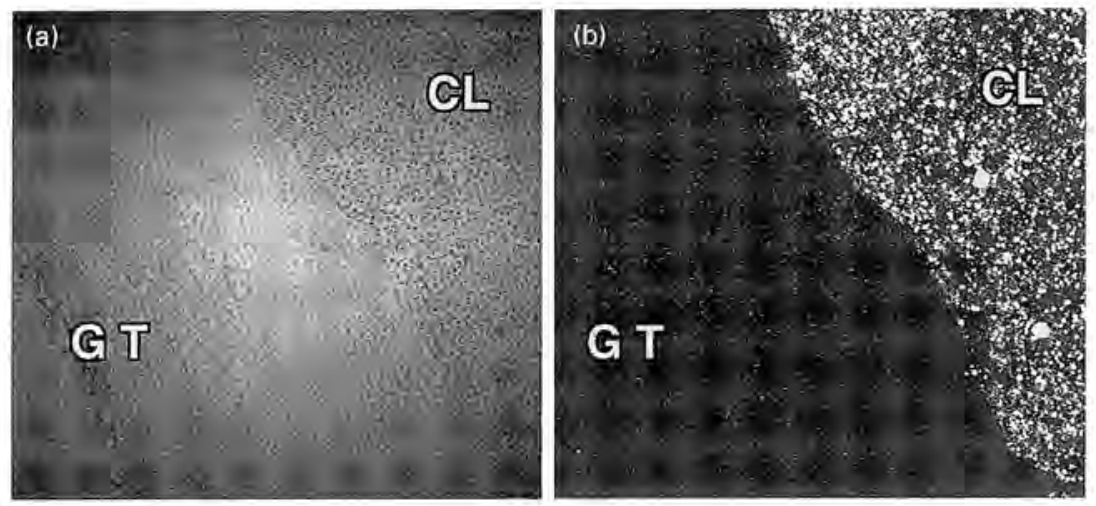

Fig. 3. Growth hormone receptor mRNA in bovine ovary measured by in situ hybridization. Photographs were taken with brightfield (a) and darkfield (b). The corpus luteum (CL) shows intense hybridization for GH receptor mRNA. Both granulosal cells (G) and thecal cells (T) of the follicle are negative for GH receptor mRNA. Original magnification $\times$ 42. Reprinted from Yuan and Lucy (1996) with permission from Elsevier Science.

\section{Direct Actions of GH on the Ovary}

\section{Localization of GH receptors within the ovary}

Growth hormone receptors are members of the cytokine-haematopoietic receptor superfamily that includes $\mathrm{GH}$ and prolactin receptors, as well as cytokine and haematopoietic hormone receptors. The $\mathrm{GH}$ receptor mediates the actions of $\mathrm{GH}$ by binding $\mathrm{GH}$, dimerizing and transducing an intracellular signal via Janus Kinase (JAK) and signal transducers and activators of transcription (STAT). Other second messenger systems, including insulin receptor substrate (IRS-1), phosphatidylinositol-3-kinase, and mitogen-activated protein (MAP) kinase, may mediate the action of GH under different conditions or cell types. The GH receptor mRNA is almost identical in cattle and sheep and contains 4160 base pairs that encode 634 amino acids. Alternative exon 1 splicing of the GH receptor mRNA occurs in a variety of species including cattle and sheep. Two different promoters transcribe two GH receptor mRNAs with alternatively spliced exon 1 sequences. One promoter (bovine/ovine 1A) has liver-specific activity. A second promoter (bovine/ovine 1B) is active in adult liver but is also active within non-hepatic tissues including the reproductive tract (Lucy et al., 1998; Fig. 2).

If $\mathrm{GH}$ has a direct effect on the ovary then the $\mathrm{GH}$ receptor should be present within ovarian cells. In cattle, the GH receptor was found within the large luteal cells (Lucy et al., 1993). The presence of GH receptor was demonstrated by using several methods including immunohistochemistry (Lucy et al., 1993), ribonuclease protection assay (Lucy et al., 1993) and in situ hybridization (Yuan and Lucy, 1996). It is not known why the GH receptor was not localized specifically within large luteal cells in pigs (Yuan and Lucy, 1996).

There may be species differences for $\mathrm{GH}$ receptor expression in ovarian follicles. In humans (Sharara and Nieman, 1994) and rats (Carlsson et al., 1993), GH receptor was detected in granulosal cells as well as corpora lutea. In cattle, GH receptor expression in follicles was approximately 20-fold lower when compared with corpora lutea (Lucy et al., 1993). Furthermore, when histological sections containing both follicles and corpora lutea were examined, corpora lutea contained abundant GH receptor protein (Lucy et al., 1993) or mRNA (Yuan and Lucy, 1996), whereas neighbouring follicles were negative for $\mathrm{GH}$ receptor (Fig. 3). However, when examined by reverse transcriptase PCR, the GH receptor was detected in bovine granulosal cells, cumulus cells and the oocyte (Izadyar et al., 1997). In addition, the GH receptor was detected in the granulosal cells and oocytes of ovine small 
follicles by in situ hybridization (Eckery et al., 1997). These results indicate that ruminant follicles contain the $\mathrm{GH}$ receptor but the concentration of $\mathrm{GH}$ receptor in follicles may be considerably lower than in corpora lutea.

\section{Does GH control ovarian IGF-I?}

Both follicles and corpora lutea have GH receptor and IGF-I mRNA. In liver, GH controls hepatic IGF-I synthesis. One important question, therefore, is whether GH controls ovarian IGF-I synthesis. Growth hormone-dependent, ovarian IGF-I synthesis has been shown in rats, pigs, and rabbits (Spicer and Echternkamp, 1995). In hypophysectomized ewes, LH increased luteal GH receptor mRNA and GH increased luteal IGF-I mRNA (Juengel et al., 1997). However, in other studies GH failed to increase ovarian IGF-I synthesis either in vitro (Wathes et al., 1995) or in intact cattle (Kirby et al., 1996). In addition, immunization of heifers against GH releasing hormone (GRF) decreased blood GH and IGF-I but did not change the ovarian IGF-I mRNA concentration (Cohick et al., 1996). Data showing GH-dependent follicular IGF-I synthesis have not been reported for sheep or cattle. Therefore, follicular IGF-I is probably not locally controlled by GH. Instead, endocrine IGF-I, under $\mathrm{GH}$ control, influences ovarian function through its contribution to follicular fluid IGF-I (Leeuwenberg et al., 1996). However, the physiological importance of locally produced (ovarian) IGF-I and endocrine IGF-I (hepatic, GH dependent) is debated because the availability of IGF-I from different sources may depend on the interaction of IGF-I with locally produced and serum-derived IGFBP (Yuan et al., 1998).

\section{In Vivo Effects of GH on Reproduction}

There is probably no absolute requirement for $\mathrm{GH}$ in reproduction, because women with inactivating GH receptor mutations (Laron dwarfs; Menashe et al., 1991) and cattle with abnormal GH receptor expression (Chase et al., 1998) are capable of reproduction. A knockout mouse for the $\mathrm{GH}$ receptor was also fertile (Zhou et al., 1997). Although reproduction is possible in each of these conditions, the efficiency of reproduction is low. Hence, there is a facilitatory but not obligatory role for $\mathrm{GH}$ in reproductive processes.

\section{Confounding effects of $G H$ and IGF-I in vivo}

A limitation of all in vivo studies using exogenous $\mathrm{GH}$ is the confounding effects of increased blood IGF-I after GH treatment. Insulin-like growth factor I is a potent ovarian grow th factor (Spicer and Echternkamp, 1995; Armstrong and Webb, 1997). Therefore, the increase in IGF-I that occurs after GH treatment confounds the direct effects of GH on the ovary. Furthermore, the increase in blood GH followed by the increase in blood IGF-I leads to an unphysiological relationship between blood GH and blood IGF-I concentrations. In untreated animals, blood GH and blood IGF-I are inversely correlated because IGF-I feeds back negatively on GH secretion. In GH-treated animals, blood GH and blood IGF-I are positively correlated (that is, GH-treated animals have high blood GH concentrations and high IGF-I). When examined in heifers fed high-energy diets, increased follicular growth was negatively correlated with serum $\mathrm{GH}$ because greater nutrient intake increased insulin and IGF-I but suppressed GH (Gutierrez et al., 1997). Therefore, the results of in vivo studies using exogenous $\mathrm{GH}$ should be interpreted with caution. Effects of exogenous $\mathrm{GH}$ in vivo are either direct effects of GH or IGF-I or a combined effect of both hormones.

\section{Number of ovarian follicles}

Administration of exogenous GH increased IGF-I as well as the number of recruited follicles (2-9 mm in diameter; Gong et al., 1997; Kirby et al., 1997). The increased number of recruited follicles 
can be maintained for at least 84 days and may persist for at least 21 days after GH treatment (Kirby et al., 1997). The greater number of recruited follicles did not lead to increased numbers of selected follicles (>10 mm diameter). Therefore, additional follicles in the recruited pool cannot proceed to larger size classes when stimulated with GH (selection process is unchanged). In controlled studies, ovulation rate was not changed in cattle treated with GH (Kirby et al., 1997). Thus, ruminants are different from mice because exogenous GH (or a GH transgene) increases ovulation rate and litter size in mice (Cecim et al, 1995). A higher proportion of twin births was reported in GH-treated cattle (Cole et al., 1991). However, the twinning response varied across herds, and may reflect an interaction of GH with either genetic or environmental factors. Indeed, Bilby and Lucy (1997) found that other factors including parity and number of corpora lutea had a greater effect on follicular growth than did exogenous GH. Pigs are similar to cattle in this respect because GH increased the number of small follicles (Spicer et al., 1992).

Hypophysectomized ewes did not develop preovulatory follicles unless GH and FSH were administered (Eckery et al, 1997). This indicates that $\mathrm{GH}$ has a direct effect on small follicles. However, the study did not preclude an indirect effect of GH on the ovary through increased IGF-I after GH treatment. Most lines of evidence support an endocrine IGF-I effect rather than a direct GH effect on ruminant follicles. First, very little GH receptor mRNA or protein is found within ruminant follicles (Lucy et al., 1993; Yuan and Lucy, 1996; Eckery et al., 1997). Second, heifers treated with increasing doses of GH failed to have greater growth of antral follicles when the GH dose was below the threshold for increased IGF-I (Gong et al., 1997). Third, cattle selected for multiple births have higher blood and follicular fluid IGF-I concentrations (Echternkamp et al., 1990). Fourth, heifers immunized against GRF had low blood IGF-I, delayed puberty, fewer large antral follicles, but equivalent ovarian IGF-I mRNA compared with control heifers (Cohick et al., 1996; Schoppee et al., 1996). Finally, cattle with a liver GH receptor deficiency, causing high blood GH with low blood IGF-I, had one quarter of the number of small antral follicles compared with control cattle (Chase et al., 1998).

The reason why the number of antral follicles is increased in animals supplemented with GH is not known. In vitro, IGF-I increases the number of gonadotrophin binding sites and the activity of gonadotrophin second messenger systems (Spicer and Echternkamp, 1995). Perhaps greater gonadotrophin action caused by GH or IGF-I can lead to an increase in follicular growth. In vivo, GH increased follicular fluid IGF-I but did not increase gonadotrophin binding sites in bovine follicles (Andrade et al., 1996). Greater gonadotrophin receptor concentration, therefore, does not occur after GH treatment in cattle. The possibility that GH or IGF-I increases the activity of gonadotrophin second messenger pathways in vivo without changing the number of gonadotrophin receptors has not been addressed. An additional possibility is that $\mathrm{GH}$ supplementation decreases atresia of the growing pool and leads to a greater number of antral follicles. In nonruminant granulosal cells, GH and IGF-I decrease apoptosis (Kaipia and Hsueh, 1997). In cattle, a GH-mediated decrease in atresia (Cushman et al, 1996) indicates that GH increases antral follicle populations by reducing atresia.

\section{Dominant and subordinate follicles}

Exogenous GH does not affect the growth rate or size of dominant follicles (Kirby et al., 1997). However, the size of second largest follicles is increased in GH-treated cows. The increase in second largest follicle diameter is associated with greater development of the recruited pool of ovarian follicles (Gong et al, 1997; Kirby et al,, 1997). Although the absolute size of the dominant follicle was not changed, the duration of the dominance phase in the first wave dominant follicle was shortened by about 2 days in $\mathrm{GH}$-treated cattle. This led to an earlier emergence of the second wave dominant follicle (Kirby et al., 1997). The shift towards a reduced period of dominance was also associated with a shift in the timing of the mid-cycle peak in blood concentration of FSH (Kirby et al., 1997). The reason for the faster turnover in dominant follicles of $\mathrm{GH}$-treated cattle is unknown. Bovine dominant follicles are dependent on $\mathrm{LH}$ for the maintenance of dominance and $\mathrm{GH}$ treatment decreases $\mathrm{LH}$ secretion (Schemm et al., 1990). In pigs, GH decreases LH/hCG binding sites within follicles (Spicer et al., 1992) but a similar response was not observed in cattle (Andrade et al., 1996). In vitro, IGF-I antagonized insulin-induced oestradiol synthesis (Spicer et al, 1993). Increased concentrations of 
GH and IGF-I, therefore, do not necessarily prolong or improve the function of dominant follicles. Instead, greater concentrations of GH and IGF-I may accelerate the series of events that lead to dominant follicle atresia and cause premature turnover of mid-cycle dominant follicles.

\section{Puberty}

Heifers immunized against GRF have lower blood concentrations of GH and IGF-I and reach puberty at an older age than control heifers (Cohick et al., 1996; Schoppee et al., 1996). The effect of GRF immunization on puberty occurred despite normal patterns of LH secretion (Schoppee et al., 1996). The delay in the timing of puberty in GRF-immunized heifers was caused by inadequate follicular oestradiol production that failed to trigger an LH surge. A synergistic relationship between GH, IGF-I and LH for puberty was demonstrated, therefore, because heifers with normal LH failed to reach puberty when GH and IGF-I were inadequate. Nutrient-restricted heifers also had delayed puberty and low IGF-I. However, unlike the GRF-immunized heifers, blood GH was increased and blood LH was decreased by nutrient restriction (Schoppee et al, 1996). Undernutrition, therefore, delays puberty through a combined effect of decreased IGF-I and LH. Treating heifers with GH increased body growth but did not decrease age at puberty or increase the number of small follicles (Hall et al. 1994). These results suggest that the initiation of LH secretion in peripubertal heifers is the most important factor that determines age at puberty. Growth hormone and IGF-I may play a role in puberty but their effects are permissive to $\mathrm{LH}$.

\section{Growth and steroidogenesis of corpora lutea}

Growth hormone is required for growth and development of the corpus luteum in ruminants because decreased corpora lutea weight in hypophysectomized ewes could be restored to near normal size with exogenous GH and LH (Juengel et al., 1997). In addition to a direct effect of GH on the corpora lutea, there may also be a requirement for endocrine IGF-I in corpora lutea growth. Cattle with a liver GH receptor deficiency (high blood GH concentrations but low blood IGF-I concentrations) had smaller corpora lutea and shorter luteal phases (Chase et al., 1998). Nutrientrestricted heifers had smaller corpora lutea, greater blood GH, and lower blood IGF-I concentrations (Vandehaar et al., 1995). In these heifers, the IGF-I mRNA in corpora lutea was not changed while the amount of IGF-I mRNA in liver was decreased by undernutrition. An endocrine mechanism involving low blood IGF-I, therefore, explained reduced corpus luteum size in nutrient-restricted heifers (Vandehaar et ah, 1995). However, in other studies of nutrient-restricted heifers, exogenous GH restored blood IGF-I to control concentrations but failed to increase corpora lutea weight (Yung et al + 1996). The effect of exogenous $\mathrm{GH}$ on the corpora lutea of intact or normal-fed cattle is equally unclear. The corpora Jutea of dairy cattle treated with $\mathrm{GH}$ from days 1-17 of an oestrous cycle were $60 \%$ heavier than those of control cattle (Lucy et al., 1995). The increase in corpora lutea weight occurred without a change in IGF-I mRNA concentration within the corpora lutea (Kirby et al., 1996). Greater plasma progesterone concentrations were reported in dairy cows treated with GH (Schemm et al, 1990; Gallo and Block, 1991). However, in other studies, GH tended to decrease plasma progesterone concentrations (Kirby et al., 1997). The inconsistencies in corpora lutea responses to GH suggest that other physiological factors may over-ride any stimulatory effect of exogenous GH on the corpora lutea. One concern for studies of GH in lactating animals is the confounding effect of increased milk production and loss of body condition on corpora lutea function in GH-treated animals. In one study of lactating cows, a period of anoestrus occurred after GH treatment (Waterman et al., 1993). Therefore, GH-induced changes in milk production may compromise corpora lutea function and confound reproductive effects of $\mathrm{GH}$.

\section{In Vitro Effects of GH on Ovarian Cells}

One method to avoid the confounding effects of endocrine IGF-I in tests of GH action is to treat ovarian cells with $\mathrm{GH}$ in vitro. The in vitro treatments can be tested further with IGF-I neutralizing 
antibodies to determine whether a GH-dependent IGF-I release is responsible for the effects of GH on reproductive cells. One detraction for most in vitro studies of $\mathrm{GH}$ is the supraphysiological doses $\left(10^{2}-10^{5} \mathrm{ng} \mathrm{ml}^{-1}\right)$ used to show an effect of $\mathrm{GH}$. This is of great concern when pituitary GH is used because of the possible contamination of the GH preparation with either LH or FSH. There are no data that show the direct activation of the JAK-STAT pathway by GH in ovarian cells. One focus of future studies should be the elucidation of $\mathrm{GH}$ signalling pathways in ovarian cells cultured in vitro. Furthermore, a physiological dose of recombinant GH should be used.

\section{Granulosal cells}

Porcine granulosal cells increase progesterone secretion in response to GH (Spicer and Echternkamp, 1995). An effect of GH on oestradiol synthesis in cultured human granulosal cells has also been demonstrated (Barreca et al., 1993). The effect of GH on steroidogenesis was blocked by the addition of a neutralizing IGF-I antibody. Therefore, the responses to GH in vitro may be secondary to an increase in IGF-I that occurs after GH treatment. There is no consensus for the effects of GH on ruminant granulosal cells. In bovine granulosal cells isolated from small or large follicles, GH inhibited oestradiol synthesis and inhibited proliferation of cells from large follicles (Spicer and Stewart, 1996). Other workers also reported an inhibitory effect of GH on the proliferation of granulosal cells from large follicles (Gong et al., 1993) but showed a stimulatory effect of GH on oestradiol secretion (Gong et al., 1994). The inhibitory effect of $\mathrm{GH}$ on cell proliferation may be explained partially by the inhibitory effect of GH on IGF-I mRNA (and perhaps protein) in bovine granulosal cells (Spicer et al., 1993). Growth hormone did not affect progesterone secretion from granulosal cells isolated from large follicles but progesterone secretion and proliferation were increased when granulosal cells were isolated from small follicles and co-treated with insulin (Spicer and Stewart, 1996). In ovine granulosal cells co-treated with insulin, $\mathrm{GH}$ also increased progesterone secretion in long-term culture (Wathes et al., 1995). One conclusion from these studies is that GH will increase steroidogenesis in cultured granulosal cells when GH causes the release of IGF-I (pig and human). The IGF-I may increase steroidogenesis itself or may be permissive to the effect of GH. An increase in steroidogenesis may not occur in ruminants because GH does not increase IGF-I in cultured granulosal cells. It may be necessary to supplement cell culture media with either insulin or IGF-I to detect any effect of GH on steroidogenesis in cultured ruminant granulosal cells.

\section{Cumulus cells}

Growth hormone increased in vitro maturation of bovine oocytes as well as cumulus expansion by an IGF-I independent mechanism (Izadyar et al., 1997). Further analyses showed that the stimulatory effects of GH were not mediated by tyrosine kinase activation. Instead, a cAMP second messenger pathway was suggested (Izadyar et al., 1997). This result was unexpected because cAMP is not a traditional GH receptor second messenger. Nevertheless, the data implicate GH in follicular control of oocyte development.

\section{Thecal cells}

Rat thecal cells increased androgen synthesis in response to GH (Apa et al., 1996a). However, the response to GH was different from that of granulosal cells, because an IGF-I antibody could not neutralize the effect of GH. In rats, therefore, GH may act on thecal cells through an IGF-Iindependent mechanism. The response of bovine thecal cells to $\mathrm{GH}$ depended on $\mathrm{LH}$ responsiveness of the cells. Growth hormone increased androstenedione secretion in thecal cells that responded well to $\mathrm{LH}$. Thecal cells that responded poorly to LH did not have increased androstenedione secretion after GH treatment (Spicer and Stewart, 1996). 


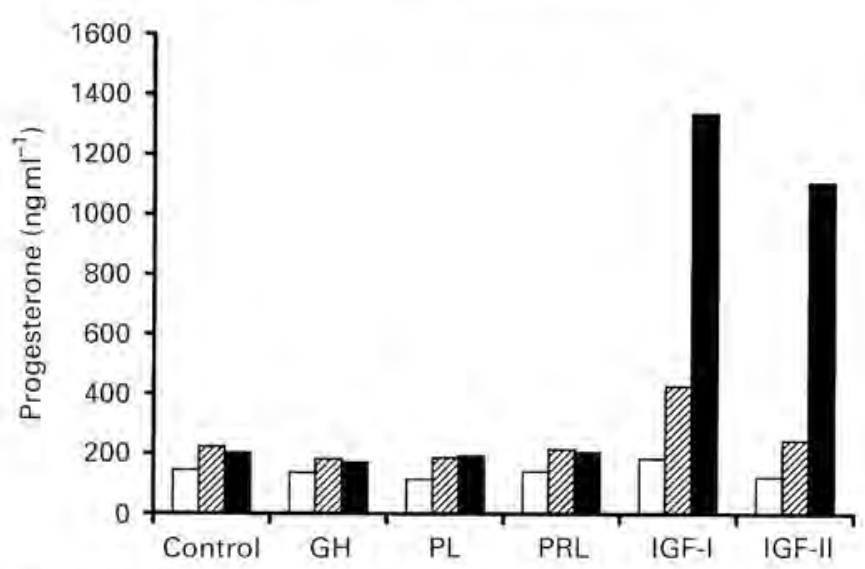

Fig. 4. Concentration of progesterone in tissue culture media from a mixed population of bovine luteal cells (oestrous cycle day 10) treated with $1 \mathrm{ng} \mathrm{ml}^{-1}(\square), 10 \mathrm{ng} \mathrm{ml}^{-1}$ (Z) or $100 \mathrm{ng} \mathrm{ml}^{-1}$ (E) bovine $\mathrm{LH}$ as well as increasing dosages of control (no hormone) or recombinant hormones [bovine growth hormone $(\mathrm{GH})$, bovine placental lactogen (PL), bovine prolactin (PRL), insulin-like growth factor I (IGF-I) or IGF-II]. Data represent secretion between 48 and $72 \mathrm{~h}$ of cell culture. Both IGF-I and IGF-II increase progesterone secretion with increasing dosage. Other hormones (GH, PL and PRL) have no effect on progesterone secretion. Data are means for duplicate wells from each of three heifers (pooled standard error = 89.5) (Lucy and Collier, unpublished).

\section{Luteal cells}

Bovine and ovine corpora lutea have increased secretion of progesterone in response to IGF-I in microdialysis systems (Sauerwein et al., 1992; Khan-Dawood et al., 1994). Furthermore, tyrosine kinase-mediated second messenger pathways for IGF-I and insulin were demonstrated for cultured bovine luteal cells (Chakravorty et al., 1993). There is no equivalent demonstration of the GH receptor second messenger system in luteal cells from any species. Nevertheless, in vitro data suggest an effect of $\mathrm{GH}$ on luteal cell steroidogenesis and oxytocin secretion. Liebermann and Schamms (1994) increased progesterone secretion and caused oxytocin release by treating bovine corpora lutea with GH in a microdialysis system. In cultured cells, GH increased progesterone secretion in human luteal cells and the effect of GH could be blocked by an IGF-I neutralizing antibody (Apa et al, 1996b). Therefore, it appears that the effects of $\mathrm{GH}$ on progesterone synthesis may depend on IGF-I synthesis. There is very little evidence that $\mathrm{GH}$ will increase steroidogenesis in cultured ruminant luteal cells. We were unable to show an effect of $\mathrm{GH}$, prolactin, or placental lactogen on bovine luteal cells. At the same time, addition of IGF-I and IGF-II resulted in greater progesterone concentrations in luteal cell cultures (Fig. 4);

\section{Conclusions}

Growth hormone is involved in many aspects of ovarian physiology in ruminants. Most importantly, GH increases the growth and development of antral follicles and increases the growth and steroidogenesis of the corpora lutea. These actions of GH are usually synergistic with IGF-I and gonadotrophins (Fig. 1). An important issue that should be addressed is the relative importance of GH compared with IGF-I for ovarian function. Many of the perceived effects of GH on the ovary can 
be explained by changes in blood IGF-I that occur when GH causes hepatic IGF-I synthesis and secretion. The ruminant may be different from pigs, humans, and laboratory animals in which GH has a direct effect on the ovary through the control of ovarian IGF-I. The presence of GH receptors in ruminant corpora lutea and follicles presumes a direct action for $\mathrm{GH}$. The direct actions of $\mathrm{GH}$ on the ovary, however, may be less important than the ovarian actions of endocrine IGF-I that are ultimately under nutritional and GH control.

\section{References}

Andrade LP, Rhind SM, Wright IA, McMillen SR, Goddard PJ and Bramley TA (1996) Effects of bovine somatotropin (bST) on ovarian function in postpartum beef cows Reproduction, Fertility and Development $8951-960$

Apa R, Caruso A, Andreani CL, Miceli E, Lazzarin N, Mastrandrea M, Ronsisvalle Ei Mancuos S and Lanaone A (1996a) Growth hormone stimulates androsterone synthesis by rat theca-interstitial cells Molecular and Cellular Endoctinology 118 95-101

Apa R, Dí Simone N, Ronsisvalle E, Miceli F, de Feo D, Caruso A, Lanzone $A$ and Mancuso S (1996b) Insulin-like growth factor (IGF)-I and IGF-II stimulate progesterone production by human luteal cells: role of IGF-I as mediator of growth hormone action Fertility and Sterility 66 235-239

Armstrong DG and Webb R (1997) Ovarian follicular dominance: the role of intraovarian growth factors and novel proteins Reviews of Reproduction 2 139-146

Barreca A, Artini PG, Del Monte P, Ponzani P, Pasquini P, Cariola G, Volpe A, Genazzani AR, Giordano G and Minuto F (1993) In vivo and in vitro effect of growth hormone on estradiol secretion by human granulosa cells lournal of Clinical Endocrinology and Metabolism 77 61-67

Bilby CR and Lucy MC (1997) Reproductive responses to bovine somatotropin (bST) in primiparous (P) and multiparous (M) cows with one or two corpora lutea (CL) Journal of Dairy Science 80 (Supplement 1) Abstact 151

Carlsson B, Nilsson A, Isaksson OGP and Billig H (1993) Growth hormone-receptor messenger RNA in the rat ovary: regulation and localization Molecular and Cellular Endocrinology 95 59-66

Cecim M, Kerr J and Bartke A (1995) Effects of bovine growth hormone (bGH) transgene expression or $\mathrm{bGH}$ treatment on reproductive functions in female mice Biology of Reproduclion 52 1144-1148

Chakravorty A, Joslyn MI and Davis JS (1993) Characterization of insulin and insulin-like growth factor-I actions in the bovine luteal cell: regulation of receptor tyrosine kinase activity, phosphatidylinositol-3-kinase, and deoxyribonucleic acid synthesis Endocrinology 133 1331-1340

Chase CC, Jr, Kirby Cl, Hammond AC, Olson TA and Lucy MC (1998) Patterns of ovarian growth and development in cattle with a growth hormone receptor deficiency fournal of Animal Science 76 212-219

Cohick WS, Armstrong JD, Whitacre MD, Lucy MC, Harvey RW and Campbell RM (1996) Ovarian expression of insulin-like growth factor-I (IGF-I), IGF binding proteins, and growth hormone $(\mathrm{GH})$ receptor in heifers actively immunized against GH-releasing factor Endocrinology 137 1670-1677

Cole WJ, Madsen KS, Hintz RL and Collier RJ (1991) Effect of recombinantly-derived bovine somatotropin on reproductive performance of dairy cattle Theriogenology 36 573-595
Cushman RA, DeSouza JC, Hedgpeth VS and Britt JH (1996) Alteration of bovine folliculogenesis by long-term treatment with estradiol (E2) and bovine somatotropin (bST) Joumal of Animal Science 74 (Supplement 1) Abstract 220

Echternkamp SE, Spicer LJ, Gregory KE, Canning SF and Hammond JM (1990) Concentrations of insulin-like growth factor-I in blood and ovarian follicular fluid of cattle selected for twins Biology of Reproduction 43 8-14

Eckery DC, Moeller CL, Nett TM and Sawyer HR (1997) Localization and quantification of binding sites for folliclestimulating hormone, luteinizing hormone, growth hormone, and insulin-like growth factor $\mathrm{T}$ in sheep ovarian follicles Biology of Reproduction 57 507-513

Gallo GF and Block E (1991) Effects of recombinant bovine somatotropin on hypophyseal and ovarian functions of lactating dairy cows Canadian Journal of Animal science 71 343-353

Gong JG, McBride D, Bramley TA and Webb R (1993) Effects of recombinant bovine somatotrophin, insulin-like growth factor- 1 and insulin on the proliferation of bovine granulosa cells in vitro. Joumal of Endocrinology 139 67-75

Gong JG, McBride D, Bramley TA and Webb R (1994) Effects of recombinant bovine somatotrophin, insulin-like growth factor-I and insulin on bovine granulosa cell steroidogenesis in vitro. Journal of Endocrinology 143 157-164

Gong JG, Baxter G, Bramley TA and Webb R (1997) Enhancement of ovarian follicle development in heifers by treatment with recombinant bovine somatotropin: a dose-response study Journal of Reproduction and Fertility 11091-97

Gutierrez CG, Oldham J, Bramley TA, Gong JG, Campbell BK and Webb R (1997) The recruitment of ovarian follicles is enhanced by increased dietary intake in heifers Journal of Animal Science 75 1876-1884

Hall JB, Schillo KK, Fitzgerald BP and Bradley NW (1994) Effects of recombinant bovine somatotropin and dietary energy intake on growth, secretion of luteinizing hormone, follicular development, and onset of puberty in beef heifers fournal of Aumal Science $72709-718$

Izadyar F, Colenbrander B and Bevers MM (1997) Stimulatory effect of growth hormone on in vitro maturation of bovine oocytes is exerted through the cyclic adenosine 3,5 monophosphate signaling pathway Biology of Reproduction 57 1484-1489

Juengel JL, Nett TM, Anthony RV and Niswender GD (1997) Effects of luteotrophic and luteolytic hormones on expression of mRNA encoding insulin-like growth factor I and growth hormone receptor in the ovine corpus luteum Jourual of Reproduction and Fertility 110 291-298

Kaipai A and Hsueh AJW (1997) Regulation of follicular atresia Aminal Review of Plysiology 59 349-363

Khan-Dawood FS, Gargiulo AR and Dawood MY (1994) In vitro microdialysis of the ovine corpus luteum of pregnancy: 
effects of insulin-like growth factor on progesterone: secretion Biology of Reproduction 51 1299-1306

Kirby CJ, Thatcher WW, Collier R], Simmen FA and Lucy MC (1996) Effects of growth hormone and pregnancy on expression of growth hormone receptor, insulin-like growth factor-I and insulin-like growth factor binding protein- 2 and -3 genes in bovine uterus, ovary and oviduct Biology of Reproduction 55 996-1002

Kirby CI, Smith MF, Keisler DH and Lucy MC (1997) Follicular function in lactating dairy cows treated with sustained release bovine somatotropin Journal of Dairy Science 80 273-285

Leeuwenberg BR, Hudson NL, Moore LG, Hurst PR and McNatty KP. (1996) Peripheral and ovarian IGF-I concentrations during the ovine oestrous cycle lournal of Endocrinology 148 281-289

Liebermann J and Schams D (1994) Actions of somatotropin on oxytocin and progesterone release from the microdialysed bovine corpus luteum in vitro. Journal of Endocrinology 143 243-250

Lucy MC, Callier RJ, Kitchell MA, Dibner J, Hauser SD and Krivi GG (1993) Immunohistochemical and nucleic acid analysis of somatotropin receptor populations in the bovine ovary Biology of Reproduction 48 1219-1227

Lucy MC, Thatcher WW, Collier RJ, Simmen FA, Ko Y, Savio JD and Badinga L (1995) Effects of somatotropin on the conceptus, uterus, and ovary during maternal recognition of pregnancy in cattle Domestic Animal Endocrinology 12 $73-82$

Lucy MC, Boyd CK, Koenigsfeld AT and Okamura CS (1998) Expression of somatotropin receptor messenger ribonucleic acid in bovine tissues Journal of Dairy Science 81 1889-1895

McGuire MA, Vicini JL, Bauman DE and Veenhuizen JJ (1992) Insulin-like growth factors and binding proteins in ruminants and their nutritional regulation fournal of Animal Science 70 2901-2910

Menashe Y, Sack J and Mashinach S (1991) Spontaneous pregnancies in two women with Laron-type dwarfism: are growth hormone and circulating insulin-like growth factor mandatory for induction of ovulation? Human Reproduction 6 670-671

Roberts AJ, Nugent RA, Klindt J and Jenkins TG (1997) Circulating insulin-like growth factor I, insulin-like growth factor binding proteins, growth hormone, and resumption of estrus in postpartum cows subjected to dietary energy restriction Journal of Animal Science 75-1909-1917

Sauerwein H, Miyamoto A, Gunther J, Meyer HHD and Schams D (1992) Binding and action of insulin-like growth factors and insulin in bovine luteal tissue during the oestrous cycle Journal of Reproduction and Fertility 96 103-115

Schemm SR, Deaver DR, Griel LC, Jr and Muller LD (1990) Effects. of recombinant bovine somatotropin on luteinizing hormone and ovarian function in lactating dairy cows Biology of Reproduction 42 815-821

Schoppee PD, Armstrong JD, Harvey RW, Whitacre MD, Felix A and Campbell RM (1996) Imumuization against growth hormone releasing factor or chronic feed restriction initiated at 3.5 months of age reduces oyarian response to pulsatile administration of gonadotrophin-releasing hormone at 6 months of age and delays onset of puberty in heifers Biology of Reproduction 55 87-98
Sharara FI and Nieman LK (1994) Identification and cellular localization of growth hormone receptor gene expression in the human ovary Tournal Clinical Endocrinology and Metabolism $79670-672$

Spicer LI and Echternkamp SE (1995) The ovarian insulin and insulin-like growth factor system with an emphasis on domestic animals Domestic Animal Endocrinology 12 223-245

Spicer LJ and Stewart RE (1996) Interaction among bovine somatotropin, insulin, and gonadotrophins on steroid production by bovine granulosa and theca cells Joumal of Dairy Science 79 813-821

Spicer LJ, Klindt J, Buonomo FC, Maurer R, Yen JT and Echternkamp SE (1992) Effect of porcine somatotropin on number of granulosa cell luteinizing hormone/human chorionic gonadotrophin receptors, oocyte viability, and concentrations of steroids and insulin-like growth factors I and $I$ in follicular fluid of lean and obese gilts journal of Animal Science 70 3149-3157

Spicer LJ, Alpizar E and Echternkamp SE (1993) Effects of insulin, insulin-like growth factor $\mathrm{I}$, and gonadotrophins on bovine granulosa cell proliferation, progesterone production, estradiol production, and(or) insulin-like growth factor I production in vitro. Journal of Animal Science 71 1232-1241

Vandehaar MJ, Sharma BK and Fogwell RL (1995) Effect of dietary energy restriction on the expression of insulin-like growth factor-1 in liver and corpus luteum of heifers Journal of Dairy Science 78 832-841

Waterman DF, Silvia WJ, Hemken RW, Heersche G, Jr, Swenson TS and Eggert RG (1993) Effect of bovine somatotropin on reproductive function in lactating dairy cows Theriogenology 40 1015-1028

Wathes DC, Perks CM and Davis AJ (1995) Regulation of insulinlike growth factor-I and progesterone synthesis by insulin and growth hormone in the ovine ovary Btology of Reproduction 53 882-889

Yuan W and Lucy MC (1996) Messenger ribonucleic acid expression for growth hormone receptor, luteinizing hormone receptor, and steroidogenic enzymes during the estrous cycle and pregnancy in porcine and bovine corpora lutea Domestic Animal Endocrinology $13431-444$

Yuan W, Bao B, Garverick HA, Youngquist RS and Lucy MC (1998) Follicular dominance in cattle is associated with divergent patterns of ovarian gene expression for insulin-like growth factor (IGF)-I, IGF-U, and IGF binding protein-2 in dominant and subordinate follicles Domestic Animal Endocrinology 15 55-63

Yung MC, VandeHaar MJ, Fogwell RL and Sharma BK (1996) Effect of energy balance and somatotropin on insulin-like growth factor $\mathrm{I}$ in serum on weight and progesterone of corpus luteum in heifers Journal of Animal Stience 74 2239-2244

Zhou Y, Xu BC, Maheshwari HG, He L, Reed M, Lozykowski M, Okada S, Cataldo L, Coschigamo K, Wagner TE, Baumann G and Kopchick JJ (1997) A mammalian model for Laron syndrome produced by targeted disruption of the mouse growth hormone receptor/binding protein gene (the Laron mouse) Proceedings of the National Acadenny of Sciences, USA 94 13215-13220 